\title{
Positioning Technology in Teaching Fashion Design
}

\author{
Yenni Idrus \\ Department of Home Economic \\ Universitas Negeri Padang \\ Padang, Indonesia \\ yennikk@gmail.com
}

\author{
Riny Arviana \\ Department of Mathematics Education \\ Postgraduate School of Universitas Pendidikan Indonesia \\ Bandung, Indonesia \\ riny.arviana@upi.edu
}

\begin{abstract}
All sectors in our world have experienced so many changes. In facing those changes, we surely should adapt it well. One of sectors that should adapt well is education, especially education for fashion design. Teaching fashion design really is not an easy work. This kind of art needs the appropriate method and strategy. Using technology in teaching fashion design does not mean we must leave the traditional method behind. Each of those two teaching ways has strength and weakness. As a teacher or lecturer of fashion design in high school or tertiary study, there are many things that we should pay attention to.
\end{abstract}

Keywords—technology; fashion design

\section{INTRODUCTION}

Fashion is one of the concentrations in vocational education. In general, vocational education is a part of education that makes a person more employable in a work group. Evans (1978) states, "There are three basic objectives of vocational education, namely: (1) meeting the needs of the community for workers; (2) add study options for learners; And (3) as motivation in developing all kinds of learning ". These three basic objectives are ideally applied in all types of vocational education, in addition to the specific objectives of each type of vocational education.

Vocational education also has certain characteristics. The following is a characteristic of vocational education stated by Young (2004): (1) Vocational education is an education that has the character of preparing for the provision of labor. Therefore the orientation of vocational education leads to graduates who can be marketed in the world of work; (2) Justification of vocational education refers to the real needs of the workforce in the business and industry; (3) The learning experiences gained through vocational education include affective, cognitive, and psychomotor aspects applied both to simulated work situations through teaching and learning, as well as real and actual work situations; (4) The success of vocational education is measured by two criteria, namely in-school success, and out-of school success. The first criterion includes the success of students in meeting the curricular requirements, while the second criterion is indicated by the success or performance of graduates after being in the real and actual workplace; (5) Vocational education has a sensitivity or responsiveness to the development of the world of work. Therefore, vocational education must be responsive and proactive to the development of science and technology, emphasizing adaptability and flexibility to face the long-term career prospects of students; (6) Workshops and laboratories are the main fittings in vocational education, to be able to realize learning situations that can reflect realistically and educative workplace situations; (7) The relationship of cooperation between vocational education institutions with business and industry is a must, along with the high demands of the relevance of vocational education programs to the demands of the business and industry.

Vocational education is different from academic education in some ways. These differences include goals, teaching, judgment, and structure. Vocational education can be provided to learners of various ages, from children to adults; and from a variety of backgrounds, from just experimental learning to college. Society needs general education, which is education that is needed by everyone. Vocational competencies and individual development require general education and special education, which is education that is only needed by some people, not everyone.

Several types of work-related are applied almost on all types of work by everyone. However, there are also some types of work that is very special and only needed by certain people only. The effectiveness of vocational education as a method depends on the following factors: (1) the teacher who considers the success of the learners; (2) objectives relevant to learners; (3) the condition of the learning environment; and (4) learning content delivered. If learners enjoy learning, then any method used in learning can be said to be effective. Teachers in vocational education want learners to learn more about what they gain from teaching in the classroom.

\section{METHOD}

This is a qualitative research. Qualitative research is a study relating to descriptive and analytical research. Subjective perception, either process or result, is taking the dominant place. Theoretical review becomes the guidance to let the focus of the research be appropriate with the reality and facts (Borg, 1989). Meanwhile, Kirk and Miller (Sudarto, 1998) define the qualitative research as a certain custom in social subject that fundamentally depends on the observation of human in its own environment. 


\section{POSITIONING TECHNOLOGY IN TEACHING FASHION DESIGN}

Clothing (fashion) initially emerged because of the need to protect the body from the weather. However, as the fashion world undergoes a gradual evolution, clothing emerges and evolves to fulfill the human desire for decoration. Emancipation of women's clothing emerged since World War I. Major changes occur in the world of fashion, ranging from abandoning the use of gill in clothing to the size of the shorter skirt. Until the beginning of this century, clothing has been enriched by the application of diverse colors and types of fabrics, the application of quite complex models, and the use of luxurious designs and ornaments. Life that became so very active to make clothing must be tailored to the needs and desires (Dunn, 1972). Decades ago, there were unwritten rules about clothing, such as when to wear hats and gloves and what colors and fabrics to use to be accepted by the public. As the level of life increases, the abundance of ideas, and technical developments in the textile field, these rules are no longer valid. A good fashion design will surely please every eye that sees and brings praise to the wearer. The models, fabrics, and colors of a dress should be interesting. Clothing must also be in accordance with the conditions, comfortable to wear, and practical. Every decoration and its accessories must have a purpose.

As we have seen the world's fashion trends are changing rapidly. To obtain an attractive fashion and in accordance with the taste of a dynamic society is certainly not easy. It takes creativity from the designers who design it. They are required to be able to produce clothing with an attractive design and motifs, beautiful color combinations, and models or styles that seem elegant. However, creativity in fashion design is not something easy. Indeed not everyone has the ability to apply creativity in designing, but with an expanded insight, regular training designs, and rewarding experiences can certainly hone and encourage the emergence of one's creativity. Fashion is a science that learns how to choose, manage and improve so as to obtain a more harmonious and beautiful clothing. Clothing and fashion are two different understandings. Clothing is everything we wear from head to toe. Meanwhile, fashion is a part of the clothing belonging to the basic clothing. In addition, fashion that is worn also can convey a message to the person who saw. In dressing many things to note and considerations so obtained clothes that match, beautiful and interesting. Teaching someone to become an expert in fashion is not an easy work. Fashion is an art that requires talent, knowledge, and habits. These three components can be explored through proper learning. Teachers or lecturers are expected to choose an effective or innovative method or strategy, especially with the rapid development of technology today. Teachers cannot ignore the use of technology in teaching the clothing. They also can not completely abandon traditional teaching.

Based on my experience and observations, so far, both teachers and lecturers usually use the method of drill in learning. Students are required to familiarize themselves with making fashion designs manually using traditional painting tools. This method has its own advantages and disadvantages. The fashion design produced in this way may seem more flexible and not rigid, because the design is directly made by hand. However, there are some disadvantages that arise when the traditional teaching method is applied to every learning material, such as the length of time required to design, the difficulty of erasing in case of error in giving the color, the resulting image is not exactly the same if the pattern of the picture is repeated, the source of an idea or inspiration, takes a long time to train the hand in making curved lines and broken lines, and requires a lot of drawing equipment and variety. The weaknesses encountered in the learning are deemed to inhibit the creativity of students in training themselves to produce designs of quality ornaments. Time that should be used by students to creativity is mostly consumed just to imitate or create decorative motif given by lecturer. In the world of education, computer information technology is growing the challenge as well as a golden opportunity. This technology can be used as an alternative choice that can be utilized in the progress of education, both in general education and vocational education. The usefulness of such technology in the world of education needs to be studied and further developed to assist the learning process, improving the quality of teaching and learning process, and the achievement of educational goals. Therefore, it is necessary to make an effort to maximize the utilization of information technology.

The presence of technology is needed to overcome the weaknesses that arise in traditional learning. Technology does not have to completely shift the traditional way of teaching (Agnew, 1996). Positioning technology in teaching art well is a must (Yahaya, 2016). Both of those ways only need to be combined in order to overcome the weaknesses that arise. One of the technologies that can be used in teaching clothing such as CorelDraw program, Adobe Photoshop, and other similar visual design programs. CorelDraw program for example, in research I've done, CorelDraw can be applied to one of the courses in Fashion Program (i.e. Decorative Design). The application of CorelDraw in the course proved able to explore students' ability to produce diverse, innovative, and creative designs in a relatively short time. Thus, the existence of technology in teaching fashion is not a threat to traditional learning. However, the technology is present as a supporter of the effective learning process of the clothing that will encourage the birth of modern future designers without losing the originality of his work.

\section{CONCLUSION AND RECOMMENDATION}

Fashion is one of sectors that are flexible because it can experience the changes anytime. This point surely gives effect on the way of teaching the fashion design to the future designers. Create the combination of technology application and traditional teaching is the perfect way. Both of them cannot eliminate each other but they can solve the weaknesses of each other. 


\section{References}

Agnew, Palmer. (1996). Multimedia in the Classroom. Massachusetts: Allyu and Bacon Needham Heights.

Borg, W.R. \& Gall, M.D. Gall..(1989). Educational Research: An Introduction, Fifth Edition. New York: Longman.

Dunn, Gloria Mortimer. (1972). Fashion Design. Adelaide: Rigby Limited.

Evans, Rupert. N. (1978). Foundations of Vocational Education Second Edition. Ohio: A Bell\&Howell Company.

Sudarto. (1995). Metodologi Penelitian Filsafat. Jakarta : Raja Grafindo Persada.

Yahaya, Wan Ahmad Jaafar Wan and Balakrishnan Muniandy. Positioning Technology and Theories in Studies and Pedagogical Application of Language, Art, and Culture. Proceeding in ISLA-5 FBS UNP 19-20 October 2016, 15-19.

Young, Michael. (2004). The Importance of Vocational Pedagogy. USA: City\&Guilds. 